\title{
The mGluR5 Antagonist MTEP Dissociates the Acquisition of Predictive and Incentive Motivational Properties of Reward-Paired Stimuli in Mice
}

\author{
Eoin C O'Connor', Hans S Crombag', Andy N Mead' ${ }^{2}$ and David N Stephens*,', \\ 'School of Psychology, University of Sussex, Brighton, Falmer, UK; 'Global Safety Pharmacology, Drug Safety Research and Development, \\ Pfizer Global Research and Development, Sandwich, UK
}

\begin{abstract}
An environmental stimulus paired with reward (a conditioned stimulus; CS) can acquire predictive properties that signal reward availability and may also acquire incentive motivational properties that enable the CS to influence appetitive behaviors. The neural mechanisms involved in the acquisition and expression of these CS properties are not fully understood. The metabotropic glutamate receptor, mGluR5, contributes to synaptic plasticity underlying learning and memory processes. We examined the role of mGluR5 in the acquisition and expression of learning that enables a CS to predict reward (goal-tracking) and acquire incentive properties (conditioned reinforcement). Mice were injected with vehicle or the mGluR5 antagonist, MTEP (3 or $10 \mathrm{mg} / \mathrm{kg}$ ), before each Pavlovian conditioning session in which a stimulus (CS +) was paired with food delivery. Subsequently, in the absence of the primary food reward, we determined whether the CS + could reinforce a novel instrumental response (conditioned reinforcement) and direct behavior toward the place of reward delivery (goal-tracking). MTEP did not affect performance during the conditioning phase, or the ability of the CS + to elicit a goal-tracking response. In contrast, $10 \mathrm{mg} / \mathrm{kg}$ MTEP given before each conditioning session prevented the subsequent expression of conditioned reinforcement. This dose of MTEP did not affect conditioned reinforcement when administered before the test, in mice that had received vehicle before conditioning sessions. Thus, mGluR5 has a critical role in the acquisition of incentive properties by a CS, but is not required for the expression of incentive learning, or for the CS to acquire predictive properties that signal reward availability. Neuropsychopharmacology (2010) 35, I807-1817; doi:I0.1038/npp.2010.48; published online 7 April 2010
\end{abstract}

Keywords: conditioned reinforcement; goal-tracking; associative learning; Pavlovian conditioning; glutamate

\section{INTRODUCTION}

As a consequence of associative learning, an environmental stimulus paired with reward experience (a conditioned stimulus; CS) not only acquires predictive properties that serve to signal the availability and/or location of the reward (discriminated approach or goal-tracking; Boakes, 1977), but may also acquire incentive properties that enable CSs to attract (auto-shaping or sign-tracking; Brown and Jenkins, 1968), energize (Pavlovian-instrumental transfer; Estes, 1948) or directly reinforce (conditioned reinforcement; Mackintosh, 1974) appetitive behaviors (see also Flagel et al, 2009; Robinson and Flagel, 2009). Although the predictive and incentive functions of CSs have clear adaptive value, the neural systems that mediate the learning

\footnotetext{
*Correspondence: Professor DN Stephens, School of Psychology, University of Sussex, JMS Building, Falmer, Brighton, East Sussex BNI 9QG, UK, Tel: + 4401273678638 , Fax: + 4401273876619 ,

E-mail: D.Stephens@sussex.ac.uk

Received 20 January 2010; revised 26 February 2010; accepted 10 March 2010
}

of incentive properties (the acquisition) and the CSs' subsequent effects on behavior (the expression) are proposed to be subverted by drugs of abuse (Everitt et al, 2001; Hyman et al, 2006; Kelley, 2004). Thus, contemporary theories of drug addiction ascribe particular importance to the role of drug-paired CSs in maintaining drug taking and triggering relapse (Everitt et al, 2001; Robinson and Berridge, 1993; Stewart et al, 1984). The powerful influence of CSs over the consumption of natural rewards (for example, cue-potentiated feeding; Weingarten, 1983; Zambie, 1973) has similarly led to the proposition that food-paired CSs may contribute to the development and maintenance of certain eating disorders and obesity (Holland and Petrovich, 2005; Volkow et al, 2008).

The neural circuitry underlying incentive learning and control over appetitive behaviors by CSs involves, in part, convergence within the striatum of dopaminergic projections from the ventral tegmental area (VTA) and substantia nigra, with glutamatergic inputs originating in the prefrontal cortex, hippocampus and amygdala (Cardinal and Everitt, 2004; Goto and Grace, 2008; Robbins and Everitt, 2002; Schultz et al, 1997). Glutamate signaling 
through ionotropic AMPA and NMDA receptors appears particularly important in mediating the expression of control over appetitive behaviors by CSs (Backstrom and Hyytia, 2006; Conrad et al, 2008; Crombag et al, 2008; Di Ciano and Everitt, 2001; Mead and Stephens, 2003a,b). However, much less is known about the role of metabotropic glutamate receptors in these incentive processes.

The group I metabotropic glutamate receptor, mGluR5, is found throughout the CNS, but is most densely expressed in the striatum, cortex and hippocampus (Romano et al, 1995). Typically located postsynaptically on dendritic spines and concentrated at perisynaptic sites (Luján et al, 1996; Shigemoto et al, 1993), mGluR5 has a central role in different forms of synaptic plasticity, including long-term potentiation (LTP; see Anwyl, 2009 for review) and longterm depression (LTD; see Bellone et al, 2008 for review), that are thought to be involved in a variety of learning and memory processes (Hyman et al, 2006; Kelley, 2004; Malenka and Bear, 2004). Mechanisms by which group I mGluRs influence synaptic plasticity include control over presynaptic transmitter release via retrograde endocannabinoid signaling (Robbe et al, 2002) and changes in postsynaptic sensitivity to excitatory input through alterations in AMPA receptor expression (Bellone and Luscher, 2005; Jo et al, 2008; Kelly et al, 2009; Mameli et al, 2007; Snyder et al, 2001; Zhang et al, 2008). Thus, mGluR5 appears ideally positioned to mediate learning processes necessary for the acquisition of predictive and/or incentive properties by reward-paired stimuli, which enable them to subsequently influence behavior.

We explored this idea using the mGluR5 antagonist, MTEP, in mice trained to associate a simple stimulus with the delivery of a food reward. By administering MTEP to mice during the learning of this stimulus-reward association (Pavlovian conditioning), we were able to examine the role of mGluR5 in the acquisition of predictive properties by the food-paired CS that serve to signal the availability of reward at its location (goal-tracking test), and incentive properties necessary to reinforce an entirely novel instrumental response (conditioned reinforcement test). To determine whether mGluR5 was necessary for the expression of control over behaviors by the CS, we administered MTEP during the tests of goal-tracking and conditioned reinforcement to mice that had received vehicle during Pavlovian conditioning sessions. Critically, tests of goal-tracking and conditioned reinforcement were performed under extinction conditions, therefore allowing the predictive and incentive motivational features of the CS to be examined without interference from presentation of the primary reward.

\section{MATERIALS AND METHODS}

\section{Subjects}

Mice ( $n=62$; male C57BL/6 $\times$ Sv129; derived in house; minimum 8 weeks old) were housed in groups of two or three and allowed to habituate to the holding room for 1 week before beginning the experiment. Animals were maintained on a 12:12 h light-dark cycle (lights on at 0700 hours) under controlled temperature $\left(21 \pm 2{ }^{\circ} \mathrm{C}\right)$ and humidity conditions $(50 \pm 5 \%)$. Body weights were maintained at approximately $85 \%$ of free-feeding weight by the provision of a limited amount of standard lab chow (B\&K Feeds, Hull, UK) approximately $2 \mathrm{~h}$ after daily experiment completion. Experiments took place during the light-phase between 0900 and 1500 hours. All procedures were performed in accordance with the United Kingdom 1986 Animals (Scientific Procedures) Act, following institutional ethical review.

\section{Drugs}

All injections were administered at a volume of $10 \mathrm{ml} / \mathrm{kg}$ i.p. The non-competitive mGluR5 antagonist, 3-((2-methyl-1, 3-thiazol-4-yl)ethynyl)pyridine (MTEP; Sequoia Research Products, Pangbourne, UK), was dissolved in $10 \% \mathrm{v} / \mathrm{v}$ Tween $80,90 \%$ water.

\section{Apparatus}

Behavioral training and testing were performed in eight standard mouse operant chambers $(15.9 \times 14 \times 12.7 \mathrm{~cm}$; Med Associates, Vermont, USA). Each chamber was housed within a sound attenuating and light-resistant cubicle, fitted with an exhaust fan that served to both ventilate the unit and mask any external noise. The front access panel, ceiling and rear wall of the conditioning chambers were constructed from clear Plexiglas and the side walls consisted of removable aluminum panels. Each chamber was fitted with a pellet dispenser system that delivered $20 \mathrm{mg}$ food pellets (5TUL, Cat no. 1811142; Test Diets, Indiana, USA) into a recessed food magazine situated at the center of one side wall. An infra red beam detected head entries into the food magazine. A retractable response lever was located on either side of the food magazine and a LED stimulus light was positioned approximately $8 \mathrm{~cm}$ above each lever. A tone generator $(2.9 \mathrm{KHz}, 5 \mathrm{~dB}$ above background) was situated between the stimulus lights. The presentation of stimuli, the delivery of food pellets and the recording of both entries into the food magazine and lever responses were performed using Med-PC IV (Med Associates).

\section{Procedure}

A summary of the experimental design is shown in Figure 1. Mice were allocated to one of three Pavlovian conditioning (PC) treatment groups that received injections of either vehicle (PC: Veh group; $n=22$ ), $3 \mathrm{mg} / \mathrm{kg}$ (PC: $3 ; n=19$ ) or $10 \mathrm{mg} / \mathrm{kg}$ (PC: $10 ; n=21$ ) i.p. MTEP before each Pavlovian conditioning session (Phase 1). Following conditioning, each conditioning treatment group (PC: Veh, 3 and 10) was exposed to two tests of conditioned reinforcement (CRf; Phase 2). Mice from each conditioning treatment group were injected with vehicle during one CRf test and MTEP during the other CRf test, the order of CRf test treatment (that is, Veh or MTEP) being counterbalanced. Specifically, group PC: Veh received $10 \mathrm{mg} / \mathrm{kg}$ MTEP during one CRf test, whereas groups PC: 3 and PC: 10 received 3 and $10 \mathrm{mg} / \mathrm{kg}$ MTEP during one CRf test, respectively. Each conditioning treatment group was then exposed to two tests of goaltracking (GT; Phase 3). As described for the CRf tests, each conditioning treatment group was injected with MTEP during one of the GT tests and vehicle during the other test; 


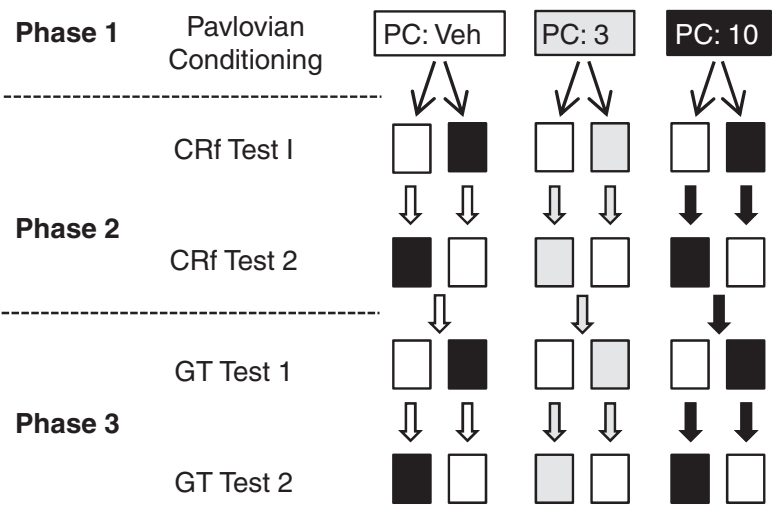

Vehicle $3 \mathrm{mg} / \mathrm{kg}$ MTEP

Figure I Experimental design summary. Mice were allocated to one of three groups that received injections of vehicle (PC: Veh), $3 \mathrm{mg} / \mathrm{kg}$ (PC: 3) or $10 \mathrm{mg} / \mathrm{kg}$ (PC: I0) MTEP before II, once daily, Pavlovian conditioning sessions (Phase I). Two tests of conditioned reinforcement (CRf; Phase 2) and goal-tracking (GT; Phase 3) were subsequently undertaken in each group. Injections of vehicle or MTEP were given before each test, the order of treatments being counterbalanced. Two Pavlovian conditioning sessions were conducted between each test (block arrows). See methods section for further details.

the order of GT test treatments being counterbalanced. Two further Pavlovian conditioning sessions were conducted between each CRf and each GT test. Mice received injections of vehicle (PC: Veh group) or 3 or $10 \mathrm{mg} / \mathrm{kg}$ MTEP (PC: 3 and 10 groups, respectively) before each reconditioning session to ensure that learning conditions were identical to those experienced during the initial conditioning phase. All drug injections were made 20 min before the start of the experimental sessions. The doses of MTEP used have previously been shown to not affect locomotor activity in mice (Cowen et al, 2007), and $3 \mathrm{mg} / \mathrm{kg}$ i.p. MTEP was reported to achieve $>75 \%$ receptor occupancy for at least $15 \mathrm{~min}$ post-dosing in mice (Anderson et al, 2003).

\section{Magazine Training}

To familiarize mice with the food reinforcer used in Pavlovian conditioning sessions, a small amount of the food was provided to mice in their home cage. The following day, mice received a single $30 \mathrm{~min}$ magazine training session in which food pellets were delivered once every $60 \mathrm{~s}$, on average (range of 25-95 s). No drug injections were made before the magazine training session and no stimuli or response levers were presented.

\section{Phase 1: Pavlovian Conditioning}

Commencing $24 \mathrm{~h}$ after the magazine training session, mice received 11, once daily, Pavlovian conditioning sessions. Each $60 \mathrm{~min}$ session consisted of 16 trials in which presentation of a stimulus was paired with food delivery $(\mathrm{CS}+)$ and 16 trials in which presentation of an alternative stimulus was not paired with food $(\mathrm{CS}-)$. The order of stimulus presentations was randomly determined and each stimulus trial was separated by a variable, no-stimulus, inter-trial interval (ITI; range of $80-120 \mathrm{~s}$; mean $=100 \mathrm{~s}$ ).

For half of the mice a constant $10 \mathrm{~s}$ tone served as the CS + and the $10 \mathrm{~s}$ flashing $(1 \mathrm{~Hz})$ of both cue lights served as the $\mathrm{CS}-$. This contingency was reversed for the remaining mice. A single food pellet was delivered $5 \mathrm{~s}$ after $\mathrm{CS}+$ onset. The total number of entries made into the food magazine during each stimulus trial ( $\mathrm{CS}+$ or $\mathrm{CS}-$ ) was recorded and expressed as a percentage of total magazine entries made during the session (percentage of magazine entries). Food magazine entries that occurred in the first five seconds following $\mathrm{CS}+$ onset (that is, before food delivery) were recorded to provide a preliminary assessment of the acquisition of goal-tracking responses. The latency to enter the food magazine following onset of the $\mathrm{CS}+$ (retrieval latency) was also measured.

\section{Phase 2: Conditioned Reinforcement}

The 60 min CRf test commenced with insertion of both response levers into the operant chamber. A single response on one lever resulted in a $1.5 \mathrm{~s}$ presentation of the $\mathrm{CS}+$, whereas a single response on the alternate lever resulted in a $1.5 \mathrm{~s}$ presentation of the CS - . For half of the mice, the left lever was designated the CS + lever and the right lever the CS - lever. This contingency was reversed for remaining mice. No food was delivered during the test. The ability of the CS + to serve as a conditioned reinforcer is shown by a greater number of responses on the $\mathrm{CS}+$ lever than on the CS- lever.

\section{Phase 3: Goal Tracking}

The GT test was $30 \mathrm{~min}$ in duration and consisted of eight trials of the $\mathrm{CS}+$, and eight trials of the CS-. The order of stimulus presentations was randomly determined and each stimulus trial was separated by a $100 \mathrm{~s}$ fixed, ITI, during which no stimuli were presented. No food was delivered during the test. The total number of entries made into the food magazine during each stimulus trial was recorded. Four mice died before completion of the GT tests, reducing the size of groups PC: 3 and PC: 10 to $n=17$ and $n=19$, respectively.

\section{Statistical Analysis}

Data were initially analyzed by mixed-factor analysis of variance (ANOVA), where the three conditioning treatment groups (PC: Veh, 3 or 10) were represented by the betweensubjects factor of PC treatment. The drug treatment (Veh or MTEP) administered to each of the three conditioning treatment groups during subsequent CRf and GT test sessions was included in analyses as a within-subjects factor of CRf treatment or GT treatment, respectively. Where a significant $(p \leqslant 0.05)$ main effect or interaction term was found, further analysis was performed using ANOVA and post hoc comparisons by two-tailed $t$-tests. To permit analysis by parametric tests, appropriate transformations were undertaken to transform skewed distributions closer to a normal distribution and to reduce heterogeneity of variance (Cardinal and Aitken, 2006). Specifically, for analysis of percentage of magazine entries (Phase 1), data were arcsine transformed $\left(Y^{\prime}=\arcsin \sqrt{ }(Y)\right)$. For analysis of magazine entries made during the first $5 \mathrm{~s}$ of $\mathrm{CS}+$ 

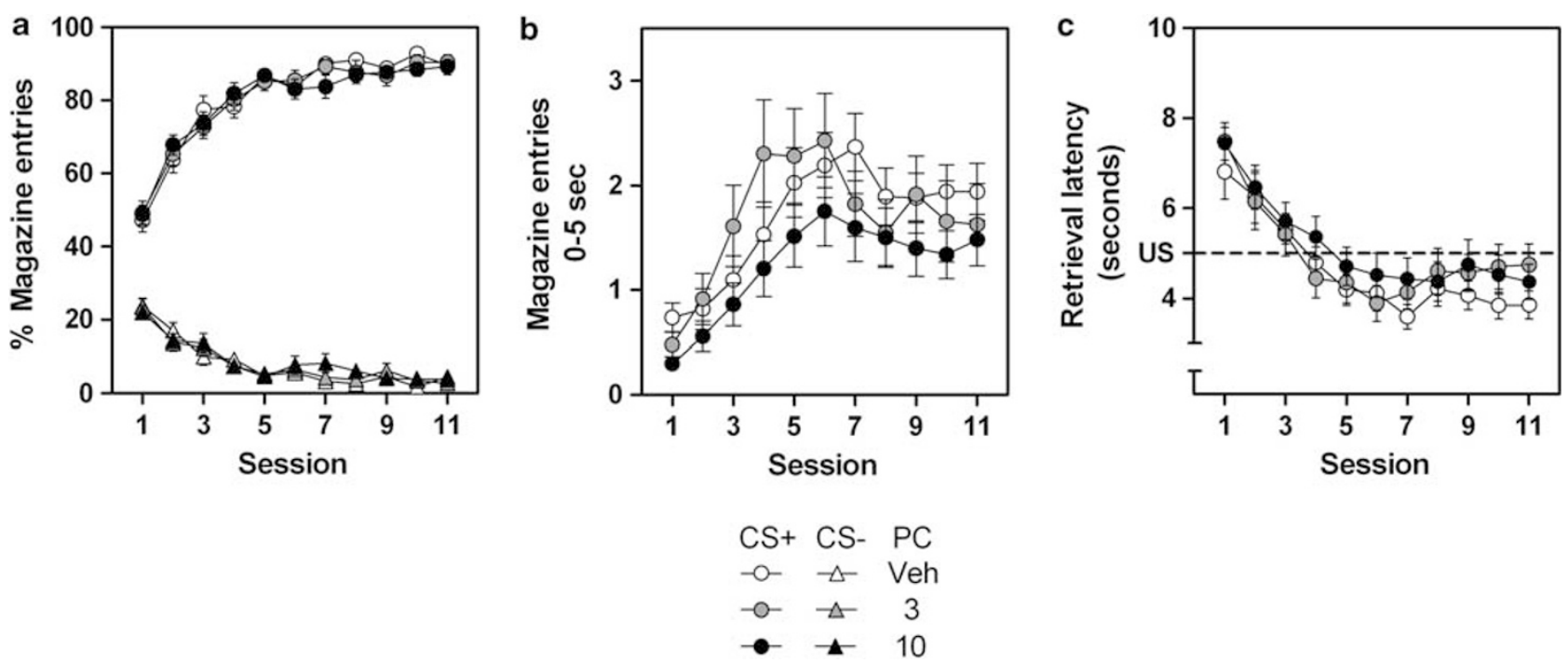

Figure 2 Measures of food magazine entry activity during I I Pavlovian conditioning sessions (Phase I) in which mice received presentations of a stimulus paired with food delivery (CS +) and a second, unpaired stimulus (CS-). Mice were injected with either vehicle or 3 or $10 \mathrm{mg} / \mathrm{kg}$ i.p. MTEP (PC: Veh, 3, or 10) 20 min before each conditioning session. (a) Magazine entries during presentation of the CS + and CS-, expressed as a percentage of total session entries (percentage of magazine entries), did not differ between conditioning treatment groups and stabilized from session 8 onward. (b) Magazine entries made during the first $5 \mathrm{~s}$ of the CS + presentation (that is, before food delivery) increased across conditioning sessions and were unaffected by treatment with MTEP. (c) The mean retrieval latency to enter the food magazine following CS + activation stabilized at 4-5 s, which corresponded with the time of food (US) delivery. Retrieval latencies did not differ among the three groups.

presentations in conditioning sessions (Phase 1), lever responses, and magazine entries in the test of CRf (Phase 2) and magazine entries in the test of goal-tracking (Phase 3 ), data were square root transformed $\left(Y^{\prime}=\sqrt{ } Y\right)$. For withinsubjects ANOVA, the Greenhouse-Geisser correction was used where the assumption of sphericity was violated. All figures show group mean $( \pm$ SEM).

\section{RESULTS}

\section{Phase 1: Pavlovian Conditioning}

Pavlovian conditioning performance did not differ between groups of mice that received either vehicle (PC: Veh group), $3 \mathrm{mg} / \mathrm{kg}$ (PC: 3 ) or $10 \mathrm{mg} / \mathrm{kg}$ (PC: 10) MTEP before each conditioning session. Across conditioning sessions, mice from all three conditioning treatment groups (PC: Veh, 3 or 10) directed a greater proportion of total session entries into the food magazine (percentage of magazine entries; Figure 2a) during presentations of the food-paired stimulus $(\mathrm{CS}+)$ than during presentations of the unpaired stimulus (CS-). This finding was confirmed by a mixed-factor ANOVA, which included stimulus $(\mathrm{CS}+$ or $\mathrm{CS}-)$ and session (1-11) as within-subjects factors. A significant difference in responding to the two stimuli across conditioning sessions was identified (main effect of stimulus, $\mathrm{F}(1,59)=1432.62, p<0.001$; stimulus $\times$ session interaction, $\mathrm{F}(10,590)=83.26, p<0.001)$. However, there was no difference between the three conditioning treatment groups in the percentage of magazine entries directed toward the stimuli (stimulus $\times$ session $\times$ conditioning treatment interaction, not significant (NS)).

The number of magazine entries made during the first $5 \mathrm{~s}$ of CS + presentations (that is, before delivery of the food reward; Figure 2b) increased across conditioning sessions (main effect of session, $\mathrm{F}(10,590)=22.01, p<0.001$ ), but did not differ between the conditioning treatment groups (session $\times$ conditioning treatment interaction, NS). In contrast, the total number of magazine entries made during CS - presentations decreased across conditioning sessions (main effect of session, $\mathrm{F}(10,590)=43.91, p<0.001$ ), but also did not differ among the conditioning treatment groups ( session $\times$ conditioning treatment interaction, NS; data not shown).

Mice came to enter the food magazine at 4-5s after CS + onset (retrieval latency; Figure 2c), corresponding with the time of food delivery. The mean retrieval latency to enter the food magazine following activation of the CS+ significantly decreased across conditioning sessions (main effect of session, $\mathrm{F}(10,590)=43.23, p<0.001)$, and there was no difference in retrieval latencies among the three conditioning treatment groups (conditioning treatment $\times$ session interaction, NS).

Stability of conditioning performance (indicated by asymptotic responding) before the first test of CRf was observed from the eighth conditioning session. Percentage of magazine entries (Figure 2a) did not differ across sessions 8-11 (main effect of Session, NS), and there was no difference between conditioning treatment groups (stimulus $\times$ session $\times$ conditioning treatment interaction, NS). Similarly, magazine entries made in first five seconds of $\mathrm{CS}+$ presentations (Figure 2b) and mean retrieval latencies (Figure 2c) did not differ across sessions 8-11 (main effect of session, NS), nor between conditioning treatment groups (session $\times$ conditioning treatment interaction, NS). No further change in conditioning performance was observed during any of the subsequent Pavlovian reconditioning sessions that occurred between the CRf and GT tests. 

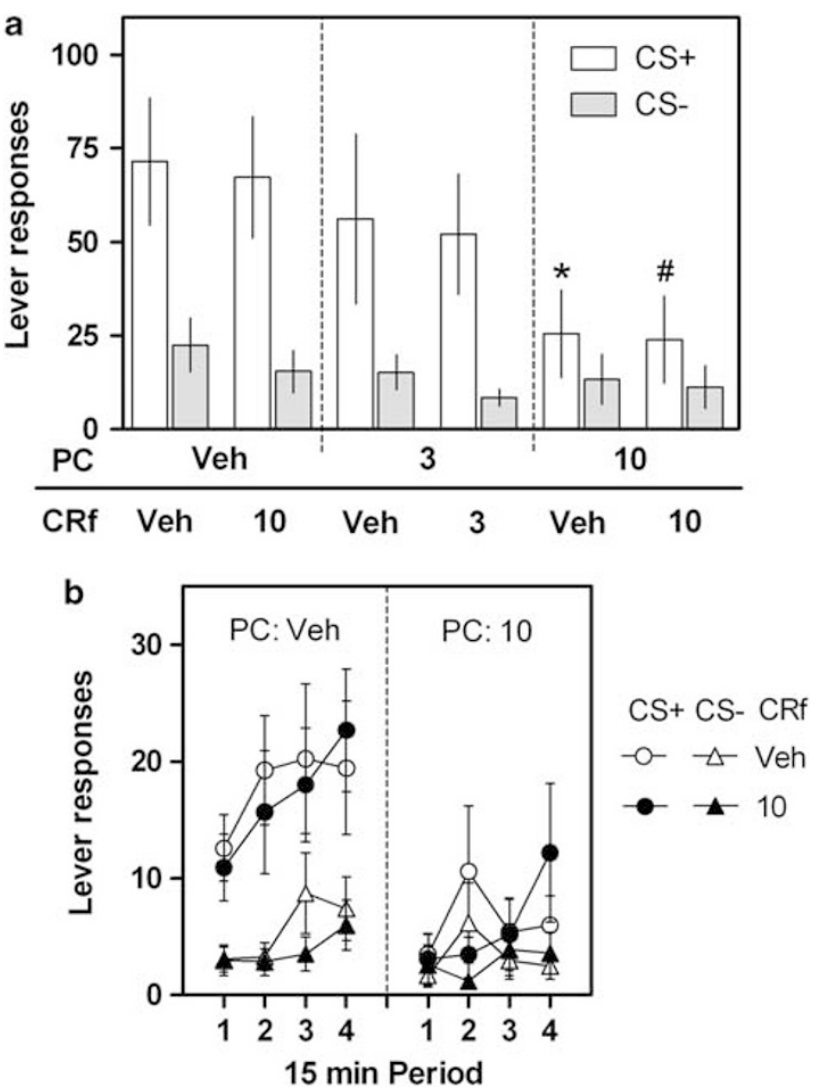

Figure 3 Lever responding in tests of conditioned reinforcement (CRf), which examines the ability of a conditioned stimulus to reinforce a novel instrumental action. In each $60 \mathrm{~min}$ test session, mice were presented with two response levers; responses on one lever led to presentation of the food-paired stimulus (CS +) and responses on the alternate lever led to presentation of the unpaired stimulus (CS-). No food was delivered during each CRf test (a) Responding for CRf was observed in mice that received vehicle or $3 \mathrm{mg} / \mathrm{kg}$ MTEP during Pavlovian conditioning (PC: Veh and 3, respectively). CRf was significantly impaired in mice that received $10 \mathrm{mg} / \mathrm{kg}$ MTEP during conditioning (PC: 10). In contrast, $10 \mathrm{mg} / \mathrm{kg}$ MTEP during the $\mathrm{CRf}$ test did not impair $\mathrm{CRf}$ in mice that received vehicle during conditioning (PC-CRf: Veh-10). ${ }^{*} p<0.05$ Post hoc, t-test comparison between Veh-Veh and I0-Veh CS + lever responses; ${ }^{*} p<0.05$ Post hoc, t-test comparison between Veh-10 and 10-10 CS + lever responses. (b) $10 \mathrm{mg} / \mathrm{kg}$ MTEP did not alter the temporal profile of lever responding in mice that received vehicle during conditioning (PC: Veh). Mice that received $10 \mathrm{mg} / \mathrm{kg}$ MTEP during conditioning (PC: 10) failed to show any significant difference in $\mathrm{CS}+$ and $\mathrm{CS}$ - lever responding in any 15-min period of each CRf test.

\section{Phase 2: Conditioned Reinforcement}

Conditioned reinforcement was influenced by the MTEP treatment given before Pavlovian conditioning sessions, but not by the MTEP treatment given during the CRf tests (Figure 3a). An initial mixed-factor ANOVA, which included Lever (CS + or CS- paired) as a within-subjects factor, confirmed that lever responding significantly differed as a result of the treatment received during conditioning sessions (lever $\times$ conditioning treatment interaction, $\mathrm{F}(2,59)=3.80, p<0.05)$. However, lever responding did not reliably differ as a result of the MTEP treatment received during the CRf test (lever $\times$ CRf treatment interaction, NS).
Within-subjects ANOVA comparisons of $\mathrm{CS}+$ and CS- lever responding, which included both CRf treatment conditions (Veh or MTEP), were undertaken to determine whether each conditioning treatment group showed CRf (that is, more responding on the CS + lever than the CS - lever). Conditioned reinforcement was shown in the PC: Veh group (main effect of lever, $\mathrm{F}(1,21)=26.53$, $p<0.001$ ) and in the PC: 3 group (main effect of lever, $\mathrm{F}(1,18)=8.55, p<0.01)$. However, the PC: 10 group failed to show any difference in CS + and CS - lever responding (main effect of lever, NS).

The impairment in responding for CRf in the PC: 10 group was due to a specific reduction in responding for the food-paired stimulus $(C S+)$, rather than a general reduction in the ability of these mice to perform an instrumental response. A mixed-factor ANOVA, performed for each stimulus-paired lever, showed that CS + lever responding was significantly influenced by the treatment received during conditioning (main effect of conditioning treatment, $\mathrm{F}(2,59)=3.59, p<0.05)$. In contrast, CS - lever responding was unaffected by the treatment received during conditioning (main effect of conditioning treatment, NS). Post hoc comparisons indicated that CS + lever responding was significantly reduced in the PC: 10 group, in comparison with the PC: Veh group during CRf tests that were preceded by injection of vehicle $(t=2.68$, d.f. $=41, p<0.05)$ and by $10 \mathrm{mg} / \mathrm{kg}$ MTEP $(t=2.70$, d.f. $=41, p<0.05)$. Consistent with a dose-related effect of MTEP, there were no differences in CS + lever responding between the PC: Veh and PC: 3 groups or the PC: 3 and PC: 10 groups in either the CRf test ( $t$-test comparisons, NS).

Although CRf was not impaired by pre-test administration of $10 \mathrm{mg} / \mathrm{kg}$ MTEP in the PC: Veh group, a possibility existed that the temporal profile of lever responding may have been altered by acute $10 \mathrm{mg} / \mathrm{kg}$ MTEP treatment. Further analysis was therefore performed to determine whether administration of $10 \mathrm{mg} / \mathrm{kg}$ MTEP in the test of CRf had any effect on the temporal profile of lever responding (Figure 3b). Conditioned reinforcement (that is, greater responding on the $\mathrm{CS}+$ lever) was evident in each 15 -min time period of the 60-min CRf test in the PC: Veh group (main effect of lever, $\mathrm{F}(1,21=25.81), p<0.001$ ), but not in the PC: 10 group (main effect of lever, NS). In the PC: Veh group, $10 \mathrm{mg} / \mathrm{kg}$ MTEP during the test of CRf did not alter the temporal profile of either CS + lever responding (Period $\times$ CRf treatment interaction, NS), or CS- lever responding (period $\times$ CRf treatment interaction, NS).

Magazine entry activity during CRf tests was also examined (Table 1), as this could provide further indication of whether MTEP administration had any gross effects on activity. A mixed-factor ANOVA of mean total magazine entries, indicated that entries were significantly increased during CRf tests in which MTEP was administered (main effect of CRf treatment, $\mathrm{F}(1,59)=11.19, p<0.01)$, but that the effect of MTEP on magazine entries did not differ among conditioning treatment groups (CRf treatment $\times$ conditioning treatment interaction, NS). Analysis of the time course of magazine entries during the CRf tests indicated that entries decreased over the course of the test session (main effect of period, $\mathrm{F}(3,177)=7.0, p<0.01)$, but the effects of MTEP given during the CRf test did not reach statistical significance (CRf treatment $\times$ period interaction, NS). 
Table I Conditioned Reinforcement: Magazine Entries

\begin{tabular}{lllllc}
\hline \multirow{2}{*}{$\begin{array}{c}\text { Group } \\
\text { (PC-CRf) }\end{array}$} & $\begin{array}{c}\text { Magazine } \\
\text { entries }\end{array}$ & \multicolumn{5}{c}{ I5-min period } \\
\cline { 3 - 7 } & Total & $\mathbf{I}$ & $\mathbf{2}$ & $\mathbf{3}$ & $\mathbf{4}$ \\
\hline Veh-Veh & $62.5(8.5)$ & $23.0(3.4)$ & $11.9(2.2)$ & $12.5(3.5)$ & $15.2(3.2)$ \\
Veh-10 & $77.7(11.0)$ & $23.0(3.8)$ & $16.9(3.3)$ & $18.5(3.7)$ & $19.2(3.0)$ \\
3-Veh & $61.5(13.4)$ & $13.3(2.6)$ & $14.7(3.0)$ & $13.6(4.0)$ & $19.9(7.4)$ \\
3-3 & $71.8(13.6)$ & $16.9(2.6)$ & $17.3(4.5)$ & $20.2(4.5)$ & $17.4(4.3)$ \\
I0-Veh & $51.8(7.7)$ & $17.2(3.4)$ & $14.5(3.0)$ & $9.5(2.0)$ & $10.6(2.9)$ \\
I0-10 & $81.5(13.1)$ & $28.7(3.5)$ & $19.0(3.9)$ & $19.8(3.6)$ & $14.0(4.0)$ \\
\hline
\end{tabular}

Head entries into the food magazine during tests of Conditioned Reinforcement (CRf). Total magazine entries were significantly increased when MTEP was administered during the CRf test; however this effect did not differ between Pavlovian conditioning (PC) treatment groups. Magazine head entries decreased across each of the 15 min periods $(I-4)$ of the $60 \mathrm{~min}$ CRf test. Table shows group mean $( \pm$ SEM).

\section{Phase 3: Goal Tracking}

Presentation of the food-paired stimulus $(\mathrm{CS}+)$, in the absence of food delivery, elicited approach responses into the food magazine (that is, towards the goal). Mice made fewer head entry responses into the magazine during presentation of the unpaired stimulus (CS - ), indicating that the CS + was able to serve as a predictor of food availability (Figure $4 \mathrm{a}$ ). There was no effect of MTEP given during the Pavlovian conditioning phase, or MTEP given during the GT test, on goal-tracking responses. These findings were confirmed by a mixed-factor ANOVA, which included stimulus (CS +, CS-) as a within-subjects factor. Mean total magazine entry responses significantly differed depending on the identity of the stimulus (main effect of stimulus, $\mathrm{F}(1,55)=200.51, p<0.001)$, but there was no effect of either the treatment received during conditioning (stimulus $\times$ conditioning treatment interaction, NS) or during the GT test (stimulus $\times$ GT treatment interaction, NS) on goal-tracking responses.

Analysis of magazine entries made during each stimulus trial was performed to determine whether acute $10 \mathrm{mg} / \mathrm{kg}$ MTEP treatment altered the profile of goal-tracking responses in the PC: Veh group and whether response profiles differed between the PC: Veh and PC: 10 groups (Figure 4b). For both PC: Veh and PC: 10 groups, the number of magazine entries made during each CS + trial decreased across the course of the GT test and few responses were made across all CS - trials. Analysis of magazine entries during $\mathrm{CS}+$ trials was performed using a mixed-factor ANOVA, which included Trial (1-8) as a within-subjects factor. This analysis confirmed that magazine entries made during each CS + trial significantly decreased with successive trials (main effect of trial, $\mathrm{F}(7,273)=17.21, p<0.001)$, but that this profile of responding was unaffected by the treatment received during conditioning (trial $\times$ conditioning treatment interaction, $\mathrm{NS}$ ), or the treatment received during the GT test (trial $\times$ GT treatment interaction, NS).
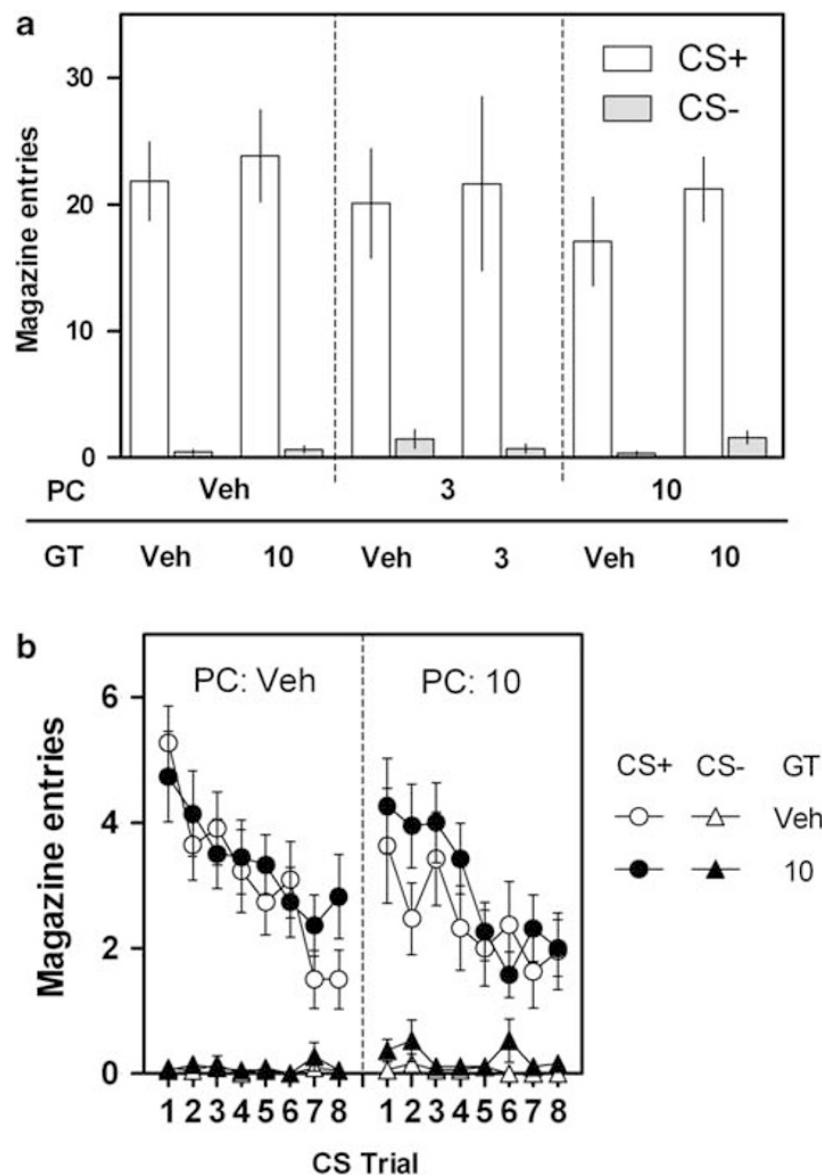

Figure 4 Food Magazine entries in tests of goal tracking (GT), which examines the ability of a conditioned stimulus to elicit approach responses to the place of food delivery. No food was delivered during each GT test. (a) Mice that received vehicle, 3 or $10 \mathrm{mg} / \mathrm{kg}$ i.p. MTEP during conditioning sessions (PC: Veh, 3 and 10 , respectively) made more entries into the food magazine during presentation of the food-paired stimulus (CS +) than during presentation of the unpaired stimulus (CS-). There was no difference in magazine activity between the conditioning treatment groups, and magazine activity was not altered by the MTEP treatment received during the GT test. (b) Magazine entries made in each CS + stimulus trial decreased across successive trials. The number of magazine entries made during each CS + stimulus trial was unaffected by the treatment (vehicle or $10 \mathrm{mg} / \mathrm{kg}$ MTEP) received during the GT test in PC: Veh and PC: 10 groups.

\section{DISCUSSION}

This study explored the effects of the selective mGluR5 antagonist, MTEP, on the acquisition of a Pavlovian association that enables a food-paired stimulus to acquire predictive properties that signal reward availability (goaltracking) and incentive properties necessary to reinforce a novel instrumental response (conditioned-reinforcement). We report that MTEP did not affect performance during Pavlovian conditioning sessions, indicating that the overall motivation to obtain food and the ability of mice to discriminate between the food-paired stimulus and the stimulus not paired with food was unaffected by blockade of mGluR5. In addition, mGluR5 function was not required for the acquisition of predictive properties necessary for the control over goal-tracking responses by the food-paired stimulus. However, mGluR5 function was critical for the 
associative learning processes necessary for the acquisition of properties by the CS that allow the CS to serve as a conditioned reinforcer, that is, providing the CS with incentive value. Once incentive learning had taken place, mGluR5 function was not required for the expression of this CS-reinforced behavior, which has been proposed to depend upon CS-elicited representations of general effect (Burke et al, 2007; Parkinson et al, 2005). These findings add important new information regarding the function of mGluR5 in the control over appetitive behaviors by reward-paired stimuli.

A potential explanation for the findings reported here is that impaired CRf in mice that had received MTEP during conditioning sessions (PC: 10 group) was due to a statedependent learning process (Stephens et al, 2000). That is, MTEP may have induced an interoceptive state during conditioning sessions and the subsequent retrieval of the CS memory during the CRf test may have been disrupted due to the presence of a different interoceptive state, namely the absence of MTEP. However, this account is unlikely since CRf responding was also impaired in the PC: 10 group when $10 \mathrm{mg} / \mathrm{kg}$ MTEP was given during the CRf test to induce the same state that existed during conditioning sessions.

That we found contrasting effects of MTEP on responding for conditioned reinforcement and goal-tracking responses may have been due to mice having experienced relatively more stimulus-food (CS-US) pairings before the GT tests than the CRf tests. Thus, goal-tracking responses may have been less susceptible to the effects of MTEP due to strengthened CS-US associations. At variance with this possibility is the observation that mice came to use the CS + as a predictor of food delivery even during Pavlovian conditioning sessions that preceded the first CRf test (Figure 2b and c). Critically, the acquisition of these goaltracking responses were unaffected by administration of MTEP, thereby supporting our proposition that mGluR5 has a dissociable role in the acquisition of predictive and incentive motivational properties by CSs.

Our findings that CRf was not impaired by administration of $10 \mathrm{mg} / \mathrm{kg}$ MTEP, during the test only, in mice that had received vehicle before conditioning sessions (PC: Veh group) is in apparent contrast to behavioral studies of cueinduced reinstatement that have reported a role of mGluR5 in the expression of control over responding maintained by both natural- and drug-paired CSs (Backstrom and Hyytia, 2006; Bespalov et al, 2005; Gass et al, 2009; Kumaresan et al, 2009; Martin-Fardon et al, 2009; Schroeder et al, 2008; Tessari et al, 2004). As it is possible that higher doses of MTEP would have reduced the expression of CRf in our study, our findings do not exclude a role of mGluR5 in the control over appetitive behaviors by reward-paired stimuli. Alternatively, subtle methodological differences may have contributed to this apparent contrast in findings. First, in our study, the CS reinforced an instrumental response that had not been previously associated with primary reinforcement. Second, mice were trained a purely Pavlovian (stimulus-outcome) association, whereas an instrumental (response-outcome) component is embedded in the acquisition of associations between environmental stimuli and reward in studies of self-administration and cue-induced reinstatement. Finally, we examined instrumental responding supported by a CS immediately following the conditioning phase, while extinction learning or periods of withdrawal are commonly employed in studies of cueinduced reinstatement and which may contribute to neural changes mediating the subsequent expression of control over appetitive behaviors by CSs (Conrad et al, 2008; Ghasemzadeh et al, 2009; Grimm et al, 2003; Lu et al, 2005).

Our finding that mGluR5 antagonism was effective in reducing a CS-reinforced behavior when administered during the acquisition of a Pavlovian association shares some similarity with studies examining the role of mGluR5 in conditioned place preference (CPP) learning. Administration of the mGluR5 antagonist 6-methyl-2-(phenylethynyl)pyridine (MPEP), during conditioning (that is, the acquisition phase), reduced the development of cocaine CPP in mice while having no effect on the development of amphetamine, ethanol, morphine or nicotine CPP (McGeehan and Olive, 2003). Another study reported that higher doses of MPEP attenuated both the acquisition and expression of morphine CPP in mice (Popik and Wrobel, 2002). In rats, the expression of cocaine CPP was unaffected by a dose of MPEP that reduced the expression of morphine CPP (Herzig and Schmidt, 2004). Thus, mGluR5 can contribute to the acquisition of associations that enable reward-paired, contextual stimuli to mediate CPP and can also influence the expression of CPP, a finding that may depend on the extent of mGluR5 blockade and/or the primary reward experienced during conditioning. However, the expression of CPP may be due to either predictive or incentive motivational associations formed between the contextual cues and the paired outcome (Stephens et al, 2010). While acknowledging that substantial differences exist between contextual $v s$ discrete cue conditioning, our findings may provide further insight into the psychological mechanisms underlying these earlier CPP reports by identifying a specific role of mGluR5 in the acquisition of incentive associations between an environmental stimulus and reward, while the ability of a reward-paired stimulus to acquire predictive properties is unaffected by mGluR5 antagonism.

An advantage of the behavioral models used in this study is that the underlying neural circuitry is relatively well characterized. Brain areas mediating control over behavior by conditioned reinforcers, and which are also rich in expression of mGluR5 (Romano et al, 1995; Shigemoto et al, 1993), include the nucleus accumbens (NAc) core of the striatum (Ito et al, 2004; Parkinson et al, 1999) and the orbitofrontal cortex (Burke et al, 2008; Pears et al, 2003). The ventral striatum is densely populated with medium spiny neurons (MSNs), that control motoric output primarily through the integration of glutamatergic inputs from the cortex, hippocampus and amygdala and dopaminergic signals arising from the VTA (Cardinal and Everitt, 2004; Grace et al, 2007). Expression of mGluR5 is found on both striatonigral and striatopallidal projection MSNs (Tallaksen-Greene et al, 1998; Testa et al, 1998) and mGluR5 has a central role in multiple forms of plasticity (Anwyl, 2009; Bellone et al, 2008) that are likely to underpin a variety of appetitive learning and memory processes (Hyman et al, 2006; Kelley, 2004; Malenka and Bear, 2004). Electrophysiological studies have shown that mGluR5 has an important role in regulating MSN excitability (D'Ascenzo et al, 2009), and is necessary for the induction of synaptic 
plasticity in the nucleus accumbens that occurs following stimulation of glutamatergic cortical inputs (Schotanus and Chergui, 2008), but is not involved in the maintenance of plasticity following its induction (Gubellini et al, 2003; Sung et al, 2001). Thus, it is particularly interesting that we found mGluR5 to be involved in the acquisition of an incentive association, but not in the expression of responding for the reward-paired CS.

At the cellular level, neuroplastic changes that occur in the NAc during associative learning, and which determine the subsequent expression of control over appetitive behaviors by CSs are likely to depend, in part, on AMPAmediated currents (Backstrom and Hyytia, 2006, 2007; Di Ciano and Everitt, 2001). Most AMPA receptors are heteromers, consisting of at least two different subunits (GluR1-GluR4), with the absence of the GluR2 subunit giving rise to higher conductance by conferring permeability to $\mathrm{Ca}^{2+}$ (Schoepfer et al, 1994). The subunit composition of AMPA receptors therefore provides a means to regulate membrane excitability, and behavioral studies have shown that incentive learning processes are influenced by AMPA receptor expression and subunit composition. For example, mice lacking the GluR1 AMPA subunit (gria1 knock out) show impaired responding for CRf (Mead and Stephens, 2003b), whereas mice lacking the GluR2 AMPA receptor subunit (gria2 knock out), show enhanced responding for a CS paired with food (Mead and Stephens, 2003a). Similarly, changes in the number and subunit composition of AMPA receptors within the NAc, following cocaine self-administration, are proposed to mediate enhanced responding for cocaine-paired stimuli (Conrad et al, 2008).

The above reports are particularly relevant because stimulation of group I mGluRs, including mGluR5, can produce changes in the expression of AMPA receptors (Bellone and Luscher, 2005Jo et al, 2008; Kelly et al, 2009; Mameli et al, 2007; Snyder et al, 2001; Waung et al, 2008; Zhang et al, 2008). In the striatum, activation of mGluR5 is required for phosphorylation of striatal GluR1-Ser831 and Ser845 (Ahn and Choe, 2009), and GluR2-Ser880 residues (Ahn and Choe, 2010). A recent study in AMPA GluR1 Ser831 mutated mice, identified that action at Ser831 was necessary for normal conditioned reinforcement (Crombag et al, 2008). Phosphorylation of GluR2-Ser880 appears critically important for the regulation of AMPA internalization during synaptic plasticity (Chung et al, 2000; Xia et al, 2000). Thus, it is tempting to propose that blockade of mGluR5 during Pavlovian conditioning in our study may have prevented alterations in the conductance, kinetics, glutamate affinity, or number, and distribution of AMPA receptors in the postsynaptic membrane that may normally be necessary for experience-dependent alterations in synaptic plasticity (Derkach et al, 2007; Shepherd and Huganir, 2007) and which subsequently determine the sensitivity to control over appetitive behaviors by rewardpaired stimuli.

However, mGluR5 has many diverse roles in the CNS, including involvement in astrocytic control over synaptic transmission and plasticity (see Haydon et al, 2009 for review) and regulation of neurotransmitter release via retrograde endocannabinoid signaling (Robbe et al, 2002). Further studies will be required to determine both the location of mGluR5 and downstream signaling pathways that are involved in mediating the effects observed in our study. Recent reports may guide these investigations by pointing to mGluR5 within limbic brain regions as being critical for the reinstatement of cocaine seeking induced by a cocaine prime (Kumaresan et al, 2009) and signaling through the extracellular signal-regulated kinase (ERK1/2) pathway as a mechanism by which mGluR5 antagonism effectively disrupts cue-induced reinstatement of alcohol seeking (Schroeder et al, 2008).

\section{CONCLUSIONS}

In this study we identify a necessary role of mGluR5 in the learning of an incentive association between an environmental stimulus and food delivery that enables the food-paired stimulus to subsequently reinforce a novel instrumental action. There is strong supporting evidence to hypothesize that these findings are due to a blockade of neuronal plasticity, mediated by changes in the expression of AMPA receptors within striatal circuits that are normally required for reward-paired cues to gain control over behavior. The acquisition of incentive associations is necessary for many aspects of adaptive behaviors, but conditioned incentives are also proposed to contribute to compulsive drug seeking and relapse observed in drug addiction (Everitt et al, 2001; Robinson and Berridge, 2000; Stewart et al, 1984), and non-homeostatic eating that may lead to obesity (Holland and Petrovich, 2005; Volkow et al, 2008). Electrophysiology studies have identified that cocaine exposure can produce long lasting plastic changes within the VTA and accumbens (Borgland et al, 2004; Chen et al, 2008; Mameli et al, 2009; Ungless et al, 2001), and mGluR5-mediated plasticity in both of these regions is involved in, or effected by, cocaine experience (Bird et al, 2010; Fourgeaud et al, 2004; Moussawi et al, 2009). The behavioral consequences of these plastic changes are still emerging, but alterations in plasticity following drug exposure may impair the ability of drug addicts to effectively learn about and/or employ strategies that could compete with drug seeking behaviors (Kalivas, 2009; Stephens and Duka, 2008). Our findings point to an interesting hypothesis that mGluR5-mediated plasticity during drug self-administration may be required for the attribution of incentive value to drug-paired cues that enable them to support drug seeking and relapse, without inducing generalized deficits in reward-learning. Secondly, disruption of mGluR5-mediated plasticity following drug experience may impair further incentive learning necessary for implementing new behaviors that could compete with drug seeking. Understanding the intricate mechanisms through which mGluR5 mediates learning and memory processes may provide therapeutic targets for a range of clinical disorders that are characterized by maladaptive responding for reward-paired cues.

\section{ACKNOWLEDGEMENTS}

We thank T Ripley for providing support with data analysis and B Halbout, J Rodriguez Parkitna and D Engblom for comments on earlier versions of this article. 


\section{DISCLOSURE}

The authors declare that, except for income received from their primary employer, no financial support or compensation has been received from any individual or corporate entity over the past 3 years for research or professional service, and there are no personal financial holdings that could be perceived as constituting potential conflict of interest. E O'Connor receives a studentship from the BBSRC and Pfizer Inc. A Mead is an employee of Pfizer Inc. Work in the senior author's laboratory is supported by the UK Medical Research Council. H. Crombag is supported by FP7 Marie Curie grant.

\section{REFERENCES}

Ahn SM, Choe ES (2009). Activation of group I metabotropic glutamate receptors increases serine phosphorylation of GluR1 alpha-amino-3-hydroxy-5-methylisoxazole-4-propionic acid receptors in the rat dorsal striatum. J Pharmacol Exp Ther 329: 1117-1126.

Ahn SM, Choe ES (2010). Alterations in GluR2 AMPA receptor phosphorylation at serine 880 following group I metabotropic glutamate receptor stimulation in the rat dorsal striatum. J Neurosci Res 88: 992-999.

Anderson JJ, Bradbury MJ, Giracello DR, Chapman DF, Holtz G, Roppe J et al (2003). In vivo receptor occupancy of mGlu5 receptor antagonists using the novel radioligand $[3 \mathrm{H}] 3-$ methoxy-5-(pyridin-2-ylethynyl)pyridine). Eur J Pharmacol 473: $35-40$.

Anwyl R (2009). Metabotropic glutamate receptor-dependent longterm potentiation. Neuropharmacology 56: 735-740.

Backstrom P, Hyytia P (2006). Ionotropic and metabotropic glutamate receptor antagonism attenuates cue-induced cocaine seeking. Neuropsychopharmacology 31: 778-786.

Backstrom P, Hyytia P (2007). Involvement of AMPA/kainate, NMDA, and mGlu5 receptors in the nucleus accumbens core in cue-induced reinstatement of cocaine seeking in rats. Psychopharmacology (Berlin) 192: 571-580.

Bellone C, Luscher C (2005). mGluRs induce a long-term depression in the ventral tegmental area that involves a switch of the subunit composition of AMPA receptors. Eur J Neurosci 21: $1280-1288$.

Bellone C, Lüscher C, Mameli M (2008). Mechanisms of synaptic depression triggered by metabotropic glutamate receptors. Cell Mol Life Sci 65: 2913-2923.

Bespalov AY, Dravolina OA, Sukhanov I, Zakharova E, Blokhina E, Zvartau E et al (2005). Metabotropic glutamate receptor (mGluR5) antagonist MPEP attenuated cue- and scheduleinduced reinstatement of nicotine self-administration behavior in rats. Neuropharmacology 49(Suppl 1): 167-178.

Bird MK, Reid CA, Chen F, Tan HO, Petrou S, Lawrence AJ (2010). Cocaine-mediated synaptic potentiation is absent in VTA neurons from mGlu5-deficient mice. Int J Neuropsychopharmacol 13: 133-141.

Boakes R (1977). Performance on learning to associate a stimulus with positive reinforcement. In: Davis H, Hurwitz HMB (eds). Operant-Pavlovian Interactions. Erlbaum, Hillsdale.

Borgland SL, Malenka RC, Bonci A (2004). Acute and chronic cocaine-induced potentiation of synaptic strength in the ventral tegmental area: electrophysiological and behavioral correlates in individual rats. J Neurosci 24: 7482-7490.

Brown PL, Jenkins HM (1968). Auto-shaping of the pigeon's keypeck. J Exp Anal Behav 11: 1-8.

Burke KA, Franz TM, Miller DN, Schoenbaum G (2007). Conditioned reinforcement can be mediated by either outcome-specific or general affective representations. Front Integr Neurosci 1: 2.
Burke KA, Franz TM, Miller DN, Schoenbaum G (2008). The role of the orbitofrontal cortex in the pursuit of happiness and more specific rewards. Nature 454: 340-344.

Cardinal RN, Aitken MRF (2006). ANOVA for the Behavioural Sciences Researcher. Lawrence Erlbaum: Mahwah, NJ.

Cardinal RN, Everitt BJ (2004). Neural and psychological mechanisms underlying appetitive learning: links to drug addiction. Curr Opin Neurobiol 14: 156-162.

Chen BT, Bowers MS, Martin M, Hopf FW, Guillory AM, Carelli RM et al (2008). Cocaine but not natural reward selfadministration nor passive cocaine infusion produces persistent LTP in the VTA. Neuron 59: 288-297.

Chung HJ, Xia J, Scannevin RH, Zhang X, Huganir RL (2000). Phosphorylation of the AMPA receptor subunit GluR2 differentially regulates its interaction with $\mathrm{PDZ}$ domain-containing proteins. J Neurosci 20: 7258-7267.

Conrad KL, Tseng KY, Uejima JL, Reimers JM, Heng LJ, Shaham Y et al (2008). Formation of accumbens GluR2-lacking AMPA receptors mediates incubation of cocaine craving. Nature 454: 118-121.

Cowen MS, Krstew E, Lawrence AJ (2007). Assessing appetitive and consummatory phases of ethanol self-administration in C57BL/ $6 \mathrm{~J}$ mice under operant conditions: regulation by mGlu5 receptor antagonism. Psychopharmacology (Berlin) 190: 21-29.

Crombag HS, Sutton JM, Takamiya K, Lee HK, Holland PC, Gallagher $M$ et al (2008). A necessary role for GluR1 serine 831 phosphorylation in appetitive incentive learning. Behav Brain Res 191: 178-183.

D’Ascenzo M, Podda MV, Fellin T, Azzena GB, Haydon P, Grassi C (2009). Activation of mGluR5 induces spike afterdepolarization and enhanced excitability in medium spiny neurons of the nucleus accumbens by modulating persistent $\mathrm{Na}+$ currents. J Physiol 587(Part 13): 3233-3250.

Derkach VA, Oh MC, Guire ES, Soderling TR (2007). Regulatory mechanisms of AMPA receptors in synaptic plasticity. Nat Rev Neurosci 8: 101-113.

Di Ciano P, Everitt BJ (2001). Dissociable effects of antagonism of NMDA and AMPA/KA receptors in the nucleus accumbens core and shell on cocaine-seeking behavior. Neuropsychopharmacology 25: 341-360.

Estes WK (1948). Discriminative conditioning; effects of a Pavlovian conditioned stimulus upon a subsequently established operant response. J Exp Psychol 38: 173-177.

Everitt BJ, Dickinson A, Robbins TW (2001). The neuropsychological basis of addictive behaviour. Brain Res Brain Res Rev 36: 129-138.

Flagel SB, Akil H, Robinson TE (2009). Individual differences in the attribution of incentive salience to reward-related cues: implications for addiction. Neuropharmacology 56(Suppl 1): 139-148.

Fourgeaud L, Mato S, Bouchet D, Hemar A, Worley PF, Manzoni OJ (2004). A single in vivo exposure to cocaine abolishes endocannabinoid-mediated long-term depression in the nucleus accumbens. J Neurosci 24: 6939-6945.

Gass JT, Osborne MP, Watson NL, Brown JL, Olive MF (2009). mGluR5 antagonism attenuates methamphetamine reinforcement and prevents reinstatement of methamphetamine-seeking behavior in rats. Neuropsychopharmacology 34: 820-833.

Ghasemzadeh MB, Vasudevan P, Mueller C, Seubert C, Mantsch JR (2009). Neuroadaptations in the cellular and postsynaptic group 1 metabotropic glutamate receptor mGluR5 and Homer proteins following extinction of cocaine self-administration. Neurosci Lett 452: $167-171$.

Goto Y, Grace AA (2008). Limbic and cortical information processing in the nucleus accumbens. Trends Neurosci 31: $552-558$.

Grace AA, Floresco SB, Goto Y, Lodge DJ (2007). Regulation of firing of dopaminergic neurons and control of goal-directed behaviors. Trends Neurosci 30: 220-227. 
Grimm JW, Lu L, Hayashi T, Hope BT, Su TP, Shaham Y (2003). Time-dependent increases in brain-derived neurotrophic factor protein levels within the mesolimbic dopamine system after withdrawal from cocaine: implications for incubation of cocaine craving. J Neurosci 23: 742-747.

Gubellini P, Saulle E, Centonze D, Costa C, Tropepi D, Bernardi G et al (2003). Corticostriatal LTP requires combined mGluR1 and mGluR5 activation. Neuropharmacology 44: 8-16.

Haydon PG, Blendy J, Moss SJ, Rob Jackson F (2009). Astrocytic control of synaptic transmission and plasticity: a target for drugs of abuse? Neuropharmacology 56(Suppl 1): 83-90.

Herzig V, Schmidt WJ (2004). Effects of MPEP on locomotion, sensitization and conditioned reward induced by cocaine or morphine. Neuropharmacology 47: 973-984.

Holland PC, Petrovich GD (2005). A neural systems analysis of the potentiation of feeding by conditioned stimuli. Physiol Behav 86: 747-761.

Hyman SE, Malenka RC, Nestler EJ (2006). Neural mechanisms of addiction: the role of reward-related learning and memory. Annu Rev Neurosci 29: 565-598.

Ito R, Robbins TW, Everitt BJ (2004). Differential control over cocaine-seeking behavior by nucleus accumbens core and shell. Nat Neurosci 7: 389-397.

Jo J, Heon S, Kim MJ, Son GH, Park Y, Henley JM et al (2008). Metabotropic glutamate receptor-mediated LTD involves two interacting $\mathrm{Ca}(2+)$ sensors, NCS-1 and PICK1. Neuron 60: 1095-1111.

Kalivas PW (2009). The glutamate homeostasis hypothesis of addiction. Nat Rev Neurosci 10: 561-572.

Kelley AE (2004). Memory and Addiction: Shared Neural Circuitry and Molecular Mechanisms. Neuron 44: 161-179.

Kelly L, Farrant M, Cull-Candy SG (2009). Synaptic mGluR activation drives plasticity of calcium-permeable AMPA receptors. Nat Neurosci 12: 593-601.

Kumaresan V, Yuan M, Yee J, Famous KR, Anderson SM, Schmidt HD et al (2009). Metabotropic glutamate receptor 5 (mGluR5) antagonists attenuate cocaine priming- and cue-induced reinstatement of cocaine seeking. Behav Brain Res 202: 238-244.

Lu L, Hope BT, Dempsey J, Liu SY, Bossert JM, Shaham Y (2005). Central amygdala ERK signaling pathway is critical to incubation of cocaine craving. Nat Neurosci 8: 212-219.

Luján R, Nusser Z, Roberts JDB, Shigemoto R, Somogyi P (1996). Perisynaptic location of metabotropic glutamate receptors mGluR 1 and mGluR5 on dendrites and dendritic spines in the rat hippocampus. Euro J Neurosci 8: 1488-1500.

Mackintosh NJ (1974). Psychol Animal Learning. Academic Press: London.

Malenka RC, Bear MF (2004). LTP and LTD: an embarrassment of riches. Neuron 44: 5-21.

Mameli M, Balland B, Lujan R, Luscher C (2007). Rapid Synthesis and Synaptic Insertion of GluR2 for mGluR-LTD in the Ventral Tegmental Area. Science 317: 530-533.

Mameli M, Halbout B, Creton C, Engblom D, Parkitna JR, Spanagel $\mathrm{R}$ et al (2009). Cocaine-evoked synaptic plasticity: persistence in the VTA triggers adaptations in the NAc. Nat Neurosci 12: 1036-1041.

Martin-Fardon R, Baptista MA, Dayas CV, Weiss F (2009). Dissociation of the effects of MTEP [3-[(2-methyl-1,3-thiazol4-yl)ethynyl]piperidine] on conditioned reinstatement and reinforcement: comparison between cocaine and a conventional reinforcer. J Pharmacol Exp Ther 329: 1084-1090.

McGeehan AJ, Olive MF (2003). The mGluR5 antagonist MPEP reduces the conditioned rewarding effects of cocaine but not other drugs of abuse. Synapse 47: 240-242.

Mead AN, Stephens DN (2003a). Involvement of AMPA receptor GluR2 subunits in stimulus-reward learning: evidence from glutamate receptor gria2 knock-out mice. J Neurosci 23: 9500-9507.
Mead AN, Stephens DN (2003b). Selective disruption of stimulusreward learning in glutamate receptor grial knock-out mice. J Neurosci 23: 1041-1048.

Moussawi K, Pacchioni A, Moran M, Olive MF, Gass JT, Lavin A et al (2009). N-Acetylcysteine reverses cocaine-induced metaplasticity. Nat Neurosci 12: 182-189.

Parkinson JA, Olmstead MC, Burns LH, Robbins TW, Everitt BJ (1999). Dissociation in effects of lesions of the nucleus accumbens core and shell on appetitive pavlovian approach behavior and the potentiation of conditioned reinforcement and locomotor activity by D-amphetamine. J Neurosci 19: 2401-2411.

Parkinson JA, Roberts AC, Everitt BJ, Di Ciano P (2005). Acquisition of instrumental conditioned reinforcement is resistant to the devaluation of the unconditioned stimulus. Q J Exp Psychol B 58: 19-30.

Pears A, Parkinson JA, Hopewell L, Everitt BJ, Roberts AC (2003). Lesions of the orbitofrontal but not medial prefrontal cortex disrupt conditioned reinforcement in primates. J Neurosci 23: 11189-11201.

Popik P, Wrobel M (2002). Morphine conditioned reward is inhibited by MPEP, the mGluR5 antagonist. Neuropharmacology 43: $1210-1217$.

Robbe D, Kopf M, Remaury A, Bockaert J, Manzoni OJ (2002). Endogenous cannabinoids mediate long-term synaptic depression in the nucleus accumbens. Proc Natl Acad Sci USA 99: 8384-8388.

Robbins TW, Everitt BJ (2002). Limbic-striatal memory systems and drug addiction. Neurobiol Learn Mem 78: 625-636.

Robinson TE, Berridge KC (1993). The neural basis of drug craving: an incentive-sensitization theory of addiction. Brain Res Brain Res Rev 18: 247-291.

Robinson TE, Berridge KC (2000). The psychology and neurobiology of addiction: an incentive-sensitization view. Addiction 95(Suppl 2): S91-S117.

Robinson TE, Flagel SB (2009). Dissociating the predictive and incentive motivational properties of reward-related cues through the study of individual differences. Biol Psychiatry 65: 869-873.

Romano C, Sesma MA, McDonald CT, O'Malley K, Van den Pol AN, Olney JW (1995). Distribution of metabotropic glutamate receptor mGluR5 immunoreactivity in rat brain. J Comp Neurol 355: 455-469.

Schoepfer R, Monyer H, Sommer B, Wisden W, Sprengel R, Kuner T et al (1994). Molecular biology of glutamate receptors. Prog Neurobiol 42: 353-357.

Schotanus SM, Chergui K (2008). Dopamine D1 receptors and group I metabotropic glutamate receptors contribute to the induction of long-term potentiation in the nucleus accumbens. Neuropharmacology 54: 837-844.

Schroeder JP, Spanos M, Stevenson JR, Besheer J, Salling M, Hodge CW (2008). Cue-induced reinstatement of alcohol-seeking behavior is associated with increased ERK1/2 phosphorylation in specific limbic brain regions: blockade by the mGluR5 antagonist MPEP. Neuropharmacology 55: 546-554.

Schultz W, Dayan P, Montague PR (1997). A neural substrate of prediction and reward. Science 275: 1593-1599.

Shepherd JD, Huganir RL (2007). The cell biology of synaptic plasticity: AMPA receptor trafficking. Annu Rev Cell Dev Biol 23: 613-643.

Shigemoto R, Nomura S, Ohishi H, Sugihara H, Nakanishi S, Mizuno N (1993). Immunohistochemical localization of a metabotropic glutamate receptor, mGluR5, in the rat brain. Neurosci Lett 163: 53-57.

Snyder EM, Philpot BD, Huber KM, Dong X, Fallon JR, Bear MF (2001). Internalization of ionotropic glutamate receptors in response to mGluR activation. Nat Neurosci 4: 1079-1085.

Stephens DN, Duka T (2008). Review. Cognitive and emotional consequences of binge drinking: role of amygdala and prefrontal cortex. Philos Trans R Soc Lond B Biol Sci 363: 3169-3179. 
Stephens DN, Duka T, Crombag HS, Cunningham CL, Heilig M, Crabbe JC (2010). Reward sensitivity: issues of measurement, and achieving consilience between human and animal phenotypes. Addict Biol 15: 145-168.

Stephens DN, Elliman TD, Dunworth SJ (2000). State-dependent behavioural sensitization: evidence from a chlordiazepoxide state. Behav Pharmacol 11: 161-167.

Stewart J, de Wit H, Eikelboom R (1984). Role of unconditioned and conditioned drug effects in the self-administration of opiates and stimulants. Psychol Rev 91: 251-268.

Sung KW, Choi S, Lovinger DM (2001). Activation of group I mGluRs is necessary for induction of long-term depression at striatal synapses. J Neurophysiol 86: 2405-2412.

Tallaksen-Greene SJ, Kaatz KW, Romano C, Albin RL (1998). Localization of mGluRla-like immunoreactivity and mGluR5like immunoreactivity in identified populations of striatal neurons. Brain Res 780: 210-217.

Tessari M, Pilla M, Andreoli M, Hutcheson DM, Heidbreder CA (2004). Antagonism at metabotropic glutamate 5 receptors inhibits nicotine- and cocaine-taking behaviours and prevents nicotine-triggered relapse to nicotine-seeking. Eur J Pharmacol 499: 121-133.

Testa CM, Friberg IK, Weiss SW, Standaert DG (1998). Immunohistochemical localization of metabotropic glutamate receptors
mGluR1a and mGluR2/3 in the rat basal ganglia. J Comp Neurol 390: 5-19.

Ungless MA, Whistler JL, Malenka RC, Bonci A (2001). Single cocaine exposure in vivo induces long-term potentiation in dopamine neurons. Nature 411: 583-587.

Volkow ND, Wang GJ, Fowler JS, Telang F (2008). Overlapping neuronal circuits in addiction and obesity: evidence of systems pathology. Philos Trans R Soc Lond B Biol Sci 363: 3191-3200.

Waung MW, Pfeiffer BE, Nosyreva ED, Ronesi JA, Huber KM (2008). Rapid translation of Arc/Arg3.1 selectively mediates mGluR-dependent LTD through persistent increases in AMPAR endocytosis rate. Neuron 59: 84-97.

Weingarten HP (1983). Conditioned cues elicit feeding in sated rats: a role for learning in meal initiation. Science 220: 431-433.

Xia J, Chung HJ, Wihler C, Huganir RL, Linden DJ (2000). Cerebellar long-term depression requires PKC-regulated interactions between GluR2/3 and PDZ domain-containing proteins. Neuron 28: 499-510.

Zambie E (1973). Augmentation of eating following a signal for feeding in rats. Learn Motiv 4: 138-147.

Zhang Y, Venkitaramani DV, Gladding CM, Zhang Y, Kurup P, Molnar E et al (2008). The Tyrosine Phosphatase STEP Mediates AMPA Receptor Endocytosis after Metabotropic Glutamate Receptor Stimulation. J Neurosci 28: 10561-10566. 